\title{
Circulation and salt balance in the São Francisco river Estuary (NE/Brazil)
}

\section{Circulação e balanço de sal no estuário do Rio São Francisco (NE/Brasil)}

\author{
Geórgenes Cavalcante ${ }^{1}$, Luiz Bruner de Miranda ${ }^{2}$ and Paulo Ricardo Petter Medeiros ${ }^{1}$ \\ ${ }^{1}$ Universidade Federal de Alagoas, Maceió, AL, Brazil \\ ${ }^{2}$ Universidade de São Paulo, São Paulo, SP, Brazil \\ E-mails: georgenes.cavalcante@icat.ufal.br (GC), bruner@usp.br (LBM), paulopetter_@hotmail.com (PRPM)
}

Received: January 05, 2017 - Revised: February 21, 2017 - Accepted: March 09, 2017

\begin{abstract}
In order to evaluate how river discharge and tidal currents forcing influence the circulation and salt transport within the São Francisco River-Estuary, a two 25 hour surveys campaigns and along-channel profiles were performed in the estuary main channel $(18 / 19$ and 25/26 February 2014). The current intensity showed higher asymmetry between flood $(\mathrm{v}<0)$ and ebb $(\mathrm{v}>0)$ currents in spring tide $(-0.6$ and $1.1 \mathrm{~m} / \mathrm{s})$, as compared to neap tide $(-0.4$ and $1.0 \mathrm{~m} / \mathrm{s})$, which was attributed to the intense buoyancy energy enhanced by the stronger discharge in spring. Overall, salinity presented high stratified conditions and varied between $0.0<\mathrm{S}<36.6$, and $0.5<\mathrm{S}<36.1$ from surface to bottom, during spring and neap, respectively. Although river discharge reduced from spring to neap tide partially mixed-highly stratified conditions (type $2 \mathrm{~b}$ ) remained in both periods, with advection and diffusion contributing with $34 \%$ and $66 \%$ to the net upstream salt flux in spring, respectively, and 56\% and 44\% in neap tide, respectively, which was attributed to the balance of tidal and baroclinic forcing and river discharge. The dominant downstream advective salt transport in both spring $\left(12.5 \mathrm{~kg} \cdot \mathrm{m}^{-1} \mathrm{~s}^{-1}\right)$ and neap $\left(15.2 \mathrm{~kg} \cdot \mathrm{m}^{-1} \mathrm{~s}^{-1}\right)$ tidal cycles suggests that there is little salt accumulation inside the São Francisco estuary.
\end{abstract}

Keywords: Circulation; Salinity; Salt transport; Stratification; São Francisco Estuary.

\section{RESUMO}

Para avaliar como a descarga do rio e as correntes de maré influenciam a circulação e o transporte de sal no estuário do rio São Francisco, foram realizadas duas campanhas de 25 horas, além de perfis ao longo do canal principal do estuário (18/19 e 25/26 de fevereiro de 2014). A velocidade das correntes mostraram uma maior assimetria entre as correntes de enchente $(\mathrm{v}<0)$ e vazante ( $\mathrm{v}>0)$ durante a sizígia $(-0,6$ e $1,1 \mathrm{~m} / \mathrm{s})$, em comparação com a maré de quadratura $(-0,4$ e 1,0 m/s). Tal resultado foi atribuído à forte energia de empuxo intensificado pela maior força da descarga fluvial na sizígia. Em geral, a salinidade apresentou forte estratificação vertical variando da superfície ao fundo entre $0,0<\mathrm{S}<36,6$ e $0,5<\mathrm{S}<36,1$, durante a sizígia e quadratura, respectivamente. Apesar de a descarga do rio ter reduzido entre a maré da sizígia e quadratura, as condições de parcialmente misturado e altamente estratificado (tipo $2 \mathrm{~b}$ ) permaneceram para ambos os períodos, com advecção e difusão turbulenta contribuindo com $34 \%$ e $66 \%$ para o transporte de sal estuário acima na sizígia, respectivamente, e $56 \%$ e $44 \%$ durante a quadratura. Tal resultado foi atribuído ao equilíbrio entre as forçantes da maré e baroclínico, além da descarga do rio. O transporte de sal advectivo predominantemente na direção estuário abaixo para os ciclos das marés de sizígia $\left(12,5 \mathrm{~kg} \mathrm{~m}^{-1} \mathrm{~s}^{-1}\right)$ e quadratura $\left(15,2 \mathrm{~kg} \mathrm{~m}^{-1} \mathrm{~s}^{-1}\right)$ sugere que há pouca acumulação de sal dentro do estuário do São Francisco.

Palavras-chave: Circulação; Salinidade; Transporte de sal; Estratificação; Estuário do São Francisco. 


\section{INTRODUCTION}

The physical environment of estuaries results from the interaction of numerous physical factors (SALOMONI et al., 2007). The most important of these are river flow, tides, sediment input, bathymetry, circulation and salinity intrusion, and, to a lesser extent, atmospheric conditions (POFF et al., 1997; TREPANIER et al., 1996). Some of these physical characteristics have undergone substantial human modification (KNOPPERS et al., 2005; MEDEIROS et al., 2011). The impacts associated with human modification reflect different types of construction used, for example, for industrial, agricultural, commercial, and residential activities (MEDEIROS et al., 2016). Such human modification of estuarine environments has resulted in dramatic modification of downstream river flow, with man-made structures (e.g., dams) being responsible for reducing the annual discharge by $30 \%$ from about $1 / 3$ of 137 rivers throughout the world (MILLIMAN et al., 2008). The São Francisco river in Brazil is no exception, and has been under intense dam construction since 1962 time (MEDEIROS et al., 2007). Such modifications to this system has resulted in reductions to the annual discharge of the São Francisco river in the lower sections of the river by more than $50 \%$ from its natural flow of $2,060 \mathrm{~m}^{3} \cdot \mathrm{s}^{-1}$ (BERNARDES et al., 2012), suppressing discharge peaks and sustaining higher river discharges during wet and drought periods respectively. The sheer extent of these artificial structures indicates the magnitude of their potential impact on estuarine equilibrium upon which circulation develop, and there is recognition that these hydrological changes can play important hydrodynamic roles in the future estuarine mixing processes, which by their very nature are related to river flow balance and salt water balance (KONDOLF, 1997).

Studies of water circulation and mixing processes in estuaries have traditionally concentrated on salinity distribution equilibrium (DYER, 1997). Overall salts provide a basis for predicting transport of conservative substances, as they are transported downstream by freshwater flow, as well as being mixed back upstream against a seaward flow produced primarily by the effects of tides, winds, and gravitational circulation (HUNKINS, 1981). Although the hydrodynamics and mixing processes of the São Francisco river-estuary play a key role in the transport of properties concentration, pollutants and in the erosion, transport and deposition of river sediments, no previous study have been undertaken to quantify the equilibrium in water circulation within this system; such lack of information includes the evaluation of fresh and salt water supply to the estuary, and the salt balance which depends on internal mixing, that is responsible for the salt transport regime within this system (CAVALCANTE et al., 2010).

To date, a significant number of studies determining hydrodynamic processes and salt balance within estuarine systems throughout the world have focused on systems with very low or very high rates of freshwater discharge $\left(2.3\right.$ to $\left.3750 \mathrm{~m}^{3} / \mathrm{s}\right)$ and varying water depths ranging from 3 to $24 \mathrm{~m}$ (e.g., CAVALCANTE et al., 2013; DAVID; KJERFVE, 1998; HUNKINS, 1981; KJERFVE, 1986; LEWIS; LEWIS, 1983; MIRANDA et al., 1998; PARK; DAVES, 1990; RESTREPO; KJERFVE, 2000). Similarly, the quantification of circulation patterns and salt transport of tropical estuaries along the northeastern Brazil is limited and has been concentrated in regional research (MIRANDA et al., 2004).

Previous work within estuarine environments in northeastern Brazil have shown a high degree of variability in mixing forcing and salt transport. For example, Araujo et al. (1999) termed the major source of energy for vertical mixing in the Joboatão river estuary (latitude $8^{\circ} 14^{\prime} \mathrm{S}$ ) being the bottom shear turbulence caused by tidal currents. Medeiros and Kjerfve (1993) observed the fresh-water input and the gravitational circulation in the Itamaraca estuary $\left(7^{\circ} 34^{\prime} \mathrm{S}\right)$ as the principal factor in determining the internal mixing. Miranda et al. (2004) termed the spring-neap variations in the net salt transport in the Curimataú estuary $\left(6^{\circ} 18^{\prime} \mathrm{S}\right)$ as driven by time varying river discharge. In other estuarine systems Lewis and Lewis (1983), David and Kjerfve (1998), and Miranda et al. (1998) observed the residual transport of water as the principal factor in determining the net salt transport.

This study is the first to quantify the internal mixing structure and net salt transport within the São Francisco River-Estuary system. This work provides an initial understanding of the system's physical processes, while focusing on the hydrodynamics in this system, describes the barotropic and baroclinic forcing exchange structures between the estuary and the adjacent coastal region. Overall we show that internal mixing within this system is wholly associated with buoyancy energy from freshwater input generating strongly stratified conditions. The salt balance within the system showed little variation between spring-neap tide cycles, with net transport pattern during river discharge the dominant forcing in the seaward salt transport, while landward salt transport was driven mainly by gravitational circulation.

\section{STUDY AREA}

The São Francisco River estuary (SFE) at the border of the states of Sergipe and Alagoas, in the northeastern tropical region, is a coastal plain tropical estuary which consists of $800 \mathrm{~km}^{2}$ of area (Figure 1), including Pleistocene-Holocene plains, river channel and pro-delta (DOMINGUEZ, 1996), and is intersected by freshwater wetlands, beach-ridges, sand dunes and mangroves forest (MEDEIROS et al., 2007; KNOPPERS et al., 2005). The estuarine channel up to the premises of the freshwater end at the town of Piaçabuçu, $15 \mathrm{~km}$ upstream from the mouth, has an area of $19.23 \mathrm{~km}^{2}$, a mean depth of $3 \mathrm{~m}$ and a maximum depth of $12 \mathrm{~m}$ at low tide conditions (MEDEIROS et al., 2016; KNOPPERS et al., 2005). The near to constant river flow after 1994 dampened the migration of the estuarine mixing zone, which is now generally set along the river mouth shoals. High wave energy and mesotidal forcing induce intense vertical mixing of the estuarine zone and constant resuspension of particulates affect chemical processes (BERNARDES et al., 2012). Other impacts induced by the diminished and more constant river flow, include severe coastal erosion, low material concentrations and loads, (KNOPPERS et al., 2005; MEDEIROS et al., 2007, 2011), loss of seasonal inundation and fertilisation of agricultural land along the river's margin and, even, rodent epidemics (BERNARDES et al., 2012). The spring and neap tidal ranges from 1.8 to $0.8 \mathrm{~m}$, respectively. 


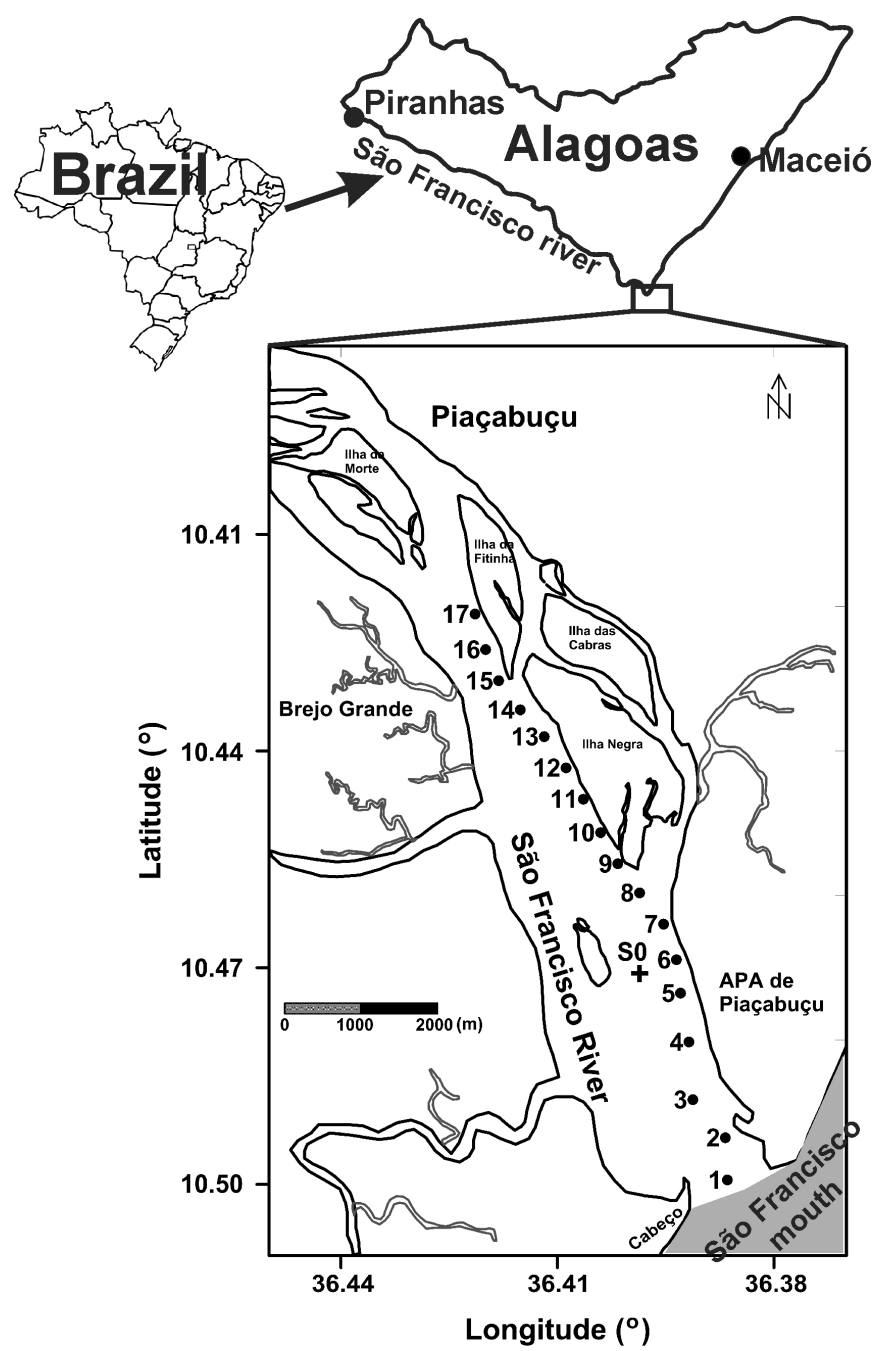

Figure 1. Oceanographic stations along the São Francisco River estuary. Station S0, was sampled during two tidal cycles in spring (18/19 February) and neap tide (25/26 February) in 2014. Along estuary stations were sampled during high slack water in the spring ( 1 to 17 ) and neap (1 to 17 ) tidal cycles, respectively.

\section{MATERIAL AND METHODS}

Observations of current velocity, temperature and salinity were obtained at an anchor station in the estuary main channel during two tidal cycles. These measurements were combined with transects along-channel around high slack water. Observations were designed to capture residual flows (MIRANDA; KJERFVE, 1998) and salt transport components after two tidal cycles (MIRANDA et al., 2004). Station selection was based on the morphology of the São Francisco river estuary, so that water parcels sampled at the mooring remained within the well-defined channel of the estuary throughout the tidal cycle, and ensuring a simpler analysis of contributions to the salt transport.

\section{Field measurements}

Vertical profiles of hydrographic properties, current speed and direction were simultaneously collected in February 2014 over two tidal cycles at anchor station S0 (Figure 1), spring tide (days 18 and 19) and neap tide (days 25 and 26), and local depth $\sim 11 \mathrm{~m}$. Hydrographic profiles were measured with a YSI 6600 conductivity-temperature-depth (CTD) multiparameter water quality monitor coupled to a YSI $650 \mathrm{MDS}$ logger at $30 \mathrm{~min}$ intervals over 25-hours which yielded a total of 50 CTD profiles at each of the two sampling campaigns. Along-channel stations (stations 1 to 17, Figure 1) were also occupied during spring and neap high slack water to estimate the upstream saline water intrusion along the river channel, before starting the 25-hours tidal cycles. A SonTek River Surveyor $1.5 \mathrm{MHz}$ (ADP) was side mounted to the boat pointing downward with the transducers $0.5 \mathrm{~m}$ below the water surface. All measurements were acquired at a vertical resolution of $0.5 \mathrm{~m}$, where each bin consisted of a $5 \mathrm{~s}$ average rate of $2 \mathrm{~Hz}$. Local wind speed and direction were recorded every $30 \mathrm{~min}$ with a Weather Station model PB200 - AIRMAR Technology fixed at the top of the boat.

\section{Data processing}

The velocity vector was decomposed and assumed the alongcomponent as (v) and cross- channel component as (u). Furthermore, these data were rotated to the axis of maximum variance (principal axis), which aligned with the bathymetry $\left(22^{\circ}\right.$ counterclockwise from east). In the classification of the estuary according to the Stratification-circulation Diagram (HANSEN; RATTRAY JUNIOR, 1966) it was assumed laterally homogeneous and the steady state condition was assumed by temporal averages during the time interval of 25 hourly measurements during neap-spring tidal cycles. The spring and neap salt transport estimations were treated as in Cavalcante et al. (2013). The summary of that approach consists of decomposing the salt transport terms into mean, tidal, steady and deviations terms. Homogeneous laterally condition was also assumed in the computation of the advective and diffusive salt transport components (MIRANDA et al., 1998, 2002). Due to the lack of river discharge measurements near the moored station (S0 - see Figure 1), the time-depth average of the velocity component (v) was taken as an approximate velocity generated by the river discharge. The correlations were obtained by decomposing the velocity and salinity profiles into four components and the instantaneous water depths into two components taking into account the main driving mechanisms: tidal (barotropic), the steady-state density-driven (baroclinic), river discharge, tidal diffusion and Stokes drift - the compensation flow opposite to the phase velocity of the progressive tidal wave. The averaged salt transport per width for one or more tidal cycles (Ts) is given by

$$
T_{s}=\frac{1}{T} \int_{0}^{T}\left[\int_{0}^{h} \rho v S d z\right] d t=<\overline{\rho v S h}>
$$

where $\varrho$ is water density, $\mathrm{v}$ is along-channel velocity component and $\mathrm{S}$ is salinity.

Due to differences in salinity between tidal cycles, the layer Richardson number $\left(\mathrm{R}_{i \mathrm{~L}}\right)$ was used to describe mixing during the tidal cycle based on Dyer and New (1986):

$$
R_{i L}=\frac{g h \Delta \rho_{v}}{\rho v^{-2}}
$$


where $g$ is gravity, $h$ is layer depth, $\Delta \rho_{v}$ is the difference between surface and bottom density, $\varrho$ is the averaged density and $\mathrm{v}$ is the along-channel component. The formulation assumes that the energy for mixing comes predominantly from the flow over the bed and, according to Miranda et al. (2004), when $\mathrm{R}_{\mathrm{iL}}<2$ velocity shear is considered sufficient to overcome stratification, and mixing generally occurs; $\mathrm{R}_{\mathrm{iL}}$ between 2 and 20 is indicative of weak stability, with moderate mixing, while $\mathrm{R}_{\mathrm{iL}}>20$ indicates strong stability with turbulent mixing across the stratification largely suppressed.

\section{RESULTS AND DISCUSSION}

\section{Hydrometeorological properties}

The average wind speed for both periods was at $\sim 3.4 \mathrm{~m} / \mathrm{s}$ with direction from east or south-east (blowing from the river mouth to the estuary main channel. The monthly long term mean and standard deviation discharge values between 1995-2014 represents the period after Xingó dam construction and ranged from $\left(3699 \mathrm{~m}^{3} / \mathrm{s} \pm 1352 \mathrm{~m}^{3} / \mathrm{s}\right)$ in January to $\left(997 \mathrm{~m}^{3} / \mathrm{s} \pm 467 \mathrm{~m}^{3} / \mathrm{s}\right)$ in September (Figure 2a), indicating the maximum and minimum monthly discharge, respectively. The long term mean in February does also indicate a high discharge average with $\left(3507 \mathrm{~m}^{3} / \mathrm{s} \pm 1642 \mathrm{~m}^{3} / \mathrm{s}\right)$ (Figure 2a). Considering the experiment period the daily-average river discharge in February 2014 ranged from 1660 to 1945 m³/s from day 1 to 7 , from which the discharge started to reduce reaching about $1100 \mathrm{~m}^{3} / \mathrm{s}$ between $18-20$ February, and the lowest values of about $900 \mathrm{~m}^{3} / \mathrm{s}$ between 25-26 February (Figure 2b). Comparing the river discharge in 2014 with the monthly long term mean discharge (Figure 2a), it clearly shows that the observed conditions are at a very low discharge conditions, as a result of several very dry years faced by the region. Such extreme weather forced the Xingó dam to reduce the minimum discharges to an already unprecedented $1000 \mathrm{~m}^{3} / \mathrm{s}$ in 2013, to an extreme low discharge rate of $900 \mathrm{3} / \mathrm{s}$ in 2014. The Brejo Grande weather stations located $10 \mathrm{~km}$ northwest from the anchor station ( $\mathrm{S} 0$ - see Figure 1) registered a light to none rainfall recorded every day with a cumulative rainfall of $43 \mathrm{~mm}$ for February 2014.

A distinct oscillation pattern was observed in velocity and salinity data, where higher ranges occurred during spring tide conditions, compared with the lower ranges observed during neap tide conditions. The time variation in the hourly vertical profiles of the along-channel component and salinity at the anchor station (Station S0) for two tidal cycles ( $25 \mathrm{~h}$ ) in the spring and neap tide conditions showed marked differences (Figures 3a-d). The vertical along-channel component profiles in the spring tide experiment (Figure 3a), indicate a clear current asymmetry as between the flood $(\mathrm{v}<0)$ and ebb $(\mathrm{v}>0)$ flow, with the extreme values varying between $-0.6 \mathrm{~m} \mathrm{~s}^{-1}$ and $1.1 \mathrm{~m} \cdot \mathrm{s}^{-1}$. Conversely, in
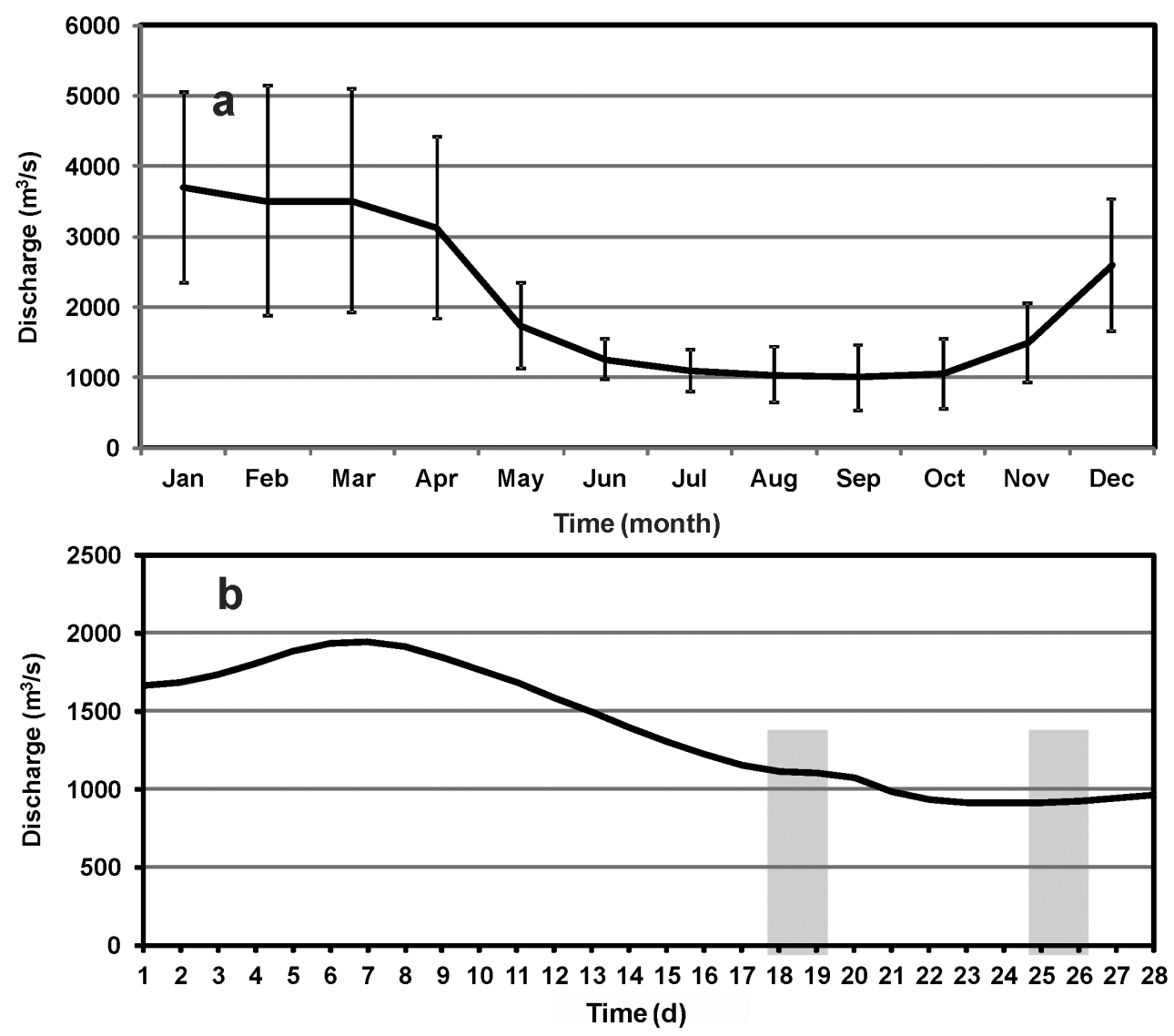

Figure 2. Monthly long term mean and standard deviation discharge in the lower São Francisco River sector after Xingó construction from 1995 to 2014 (a), and daily river discharge according to the experiment period 18-19 and 25-26 February 2014 (b). 

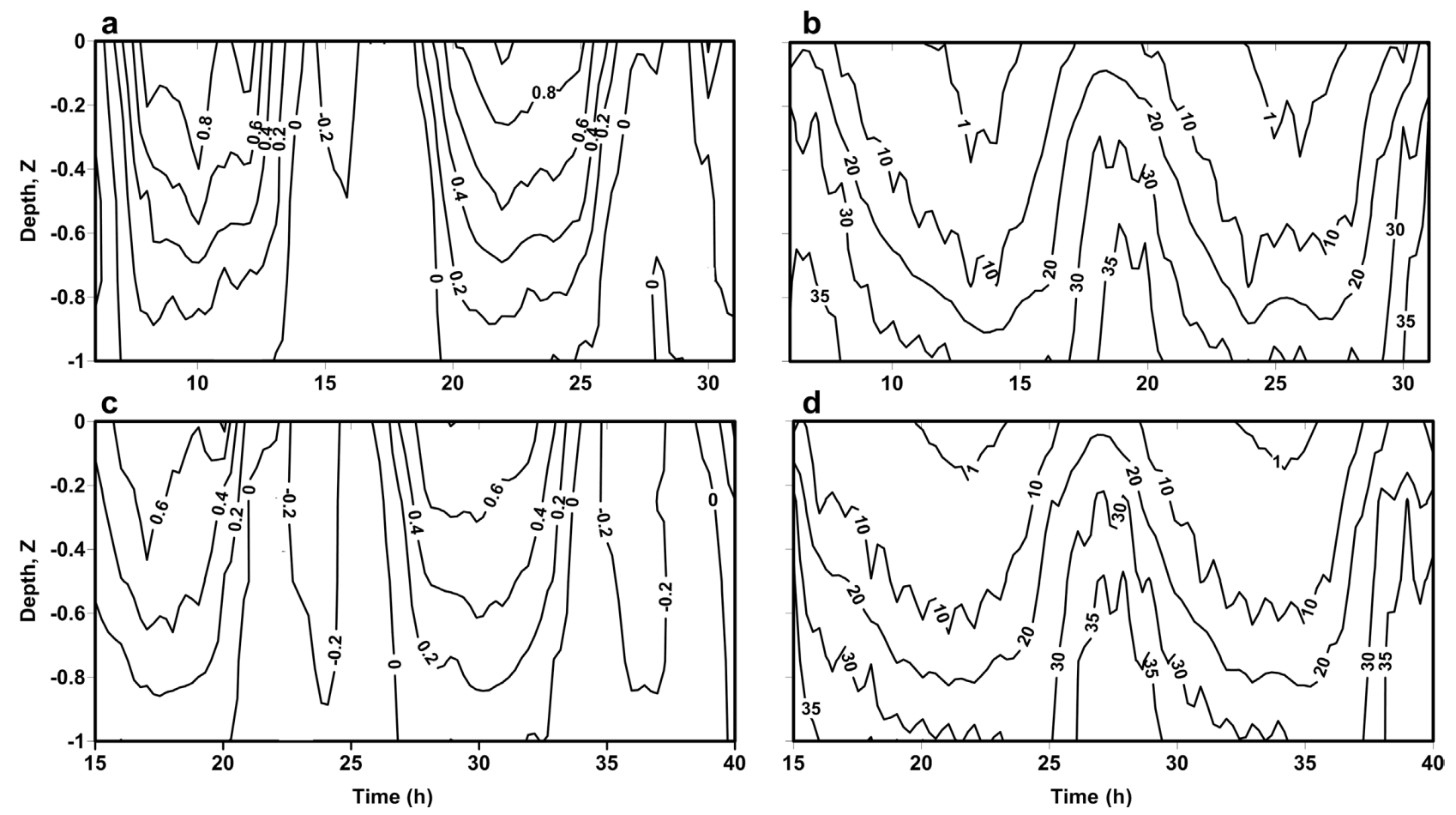

Figure 3. Temporal and vertical variation of the (v) along-channel component $\left(\mathrm{ms}^{-1}\right)$ and salinity at the spring $(\mathrm{a}, \mathrm{b})$ and neap $(\mathrm{c}, \mathrm{d})$ tide cycles (18-19 and 25-26 February, 2014, respectively). Positive current speed means downstream and negative means upstream.

the neap tide experiment reduction of the ebb/flood current asymmetry was present with values varying between $-0.4 \mathrm{~m} \mathrm{~s}^{-1}$ and $1.0 \mathrm{~m} . \mathrm{s}^{-1}$, respectively (Figure $3 \mathrm{c}$ ). The salinity variations showed differences among spring and neap tide periods (Figures 3b, 3d), and represents the influence of tidal current and river discharge components. The hourly vertical salinity profiles on spring experiment indicate periods where the halocline intensification and erosion are apparent with surface and near-bottom salinity varying between 0.0-15.9 and 27.6-36.3, respectively (Figure 3b). The surface and near-bottom salinity during neap tide revealed similar pattern as compared to spring tide and indicate a variation within the ranges 0.5-21.8 and 26.9-36.1, respectively (Figure 3d). Although there was a pronounced vertical salinity oscillation on both spring and neap tide experiments, temperature showed relatively low variation from surface to bottom remaining almost constant within the range of $27.8-29.6^{\circ} \mathrm{C}$.

There was a significant distortion between flood-ebb currents and salinity distribution throughout spring-neap tide experiments. In general, the flood-ebb asymmetry in current was more significant during the spring tide, while stratification and shear intensification/relaxation were dependent on the tidal currents, leading to maximum stratification and shear during maximum flood currents, and not exceeding the maximum ebb currents (PARK; DAVES, 1990; MIRANDA et al., 2012). Potential explanations for the observed greater asymmetry during the sampled spring tidal condition were twofold. First, the presence of strong river discharge that remained constant in the region during the spring tidal period resulted in an seaward current strength during the last stage of the ebb period (MANTOVANELLI et al., 2004), and second, a slightly high flood currents within the estuary main channel due to the high tide conditions contributed to enhance the coastal water flow into the estuary (VAZ et al., 2005). Moreover, as mentioned earlier, the predominant wind blows towards the estuary head at SE-NW direction, which might also contribute in strengthen the upstream currents (ALI et al., 2010; LEWIS; LEWIS, 1983). On the other hand, our data show that salinity remained stratified in both spring-neap tides indicating a minimum salinity gradient during low water as a result of the advective flux pushing less saline water downstream during the ebb tide, similar to what was found by Miranda et al. (2004). Even though during the neap-tidal cycle the river discharge decreased generating less asymmetry on longitudinal current it did not played a role on modifying the vertical salinity structure remaining highly stratified, which suggest that the balance of tidal and baroclinic forcing and river discharge are indeed the main physical components acting on this system.

\section{Vertical mixing and saline intrusion}

The layer Richardson number computed for spring-neap tide cycles are presented in Figures $4 \mathrm{a}, 4 \mathrm{~b}$. The high $\mathrm{Ri}_{\mathrm{L}}$ found in both tidal cycles is indicative of strong stability, with turbulent mixing across the stratification largely suppressed. The high temporal variability shows that these stratified conditions persist over the tidal cycles. During the spring-neap tidal cycle there was a cyclic temporal variation in the $\mathrm{Ri}_{\mathrm{L}}$ remaining under stable conditions (Figures $4 \mathrm{a}, 4 \mathrm{~b}$ ); most of the time the number was above 100 , reaching values near $10^{5}$, associated with a high stratified halocline. The layer Richardson number formulation is a simplification of the Richardson number, which relies on the assumption that the energy for mixing comes predominantly from the flow over the bed, and that the internal shear is negligible 

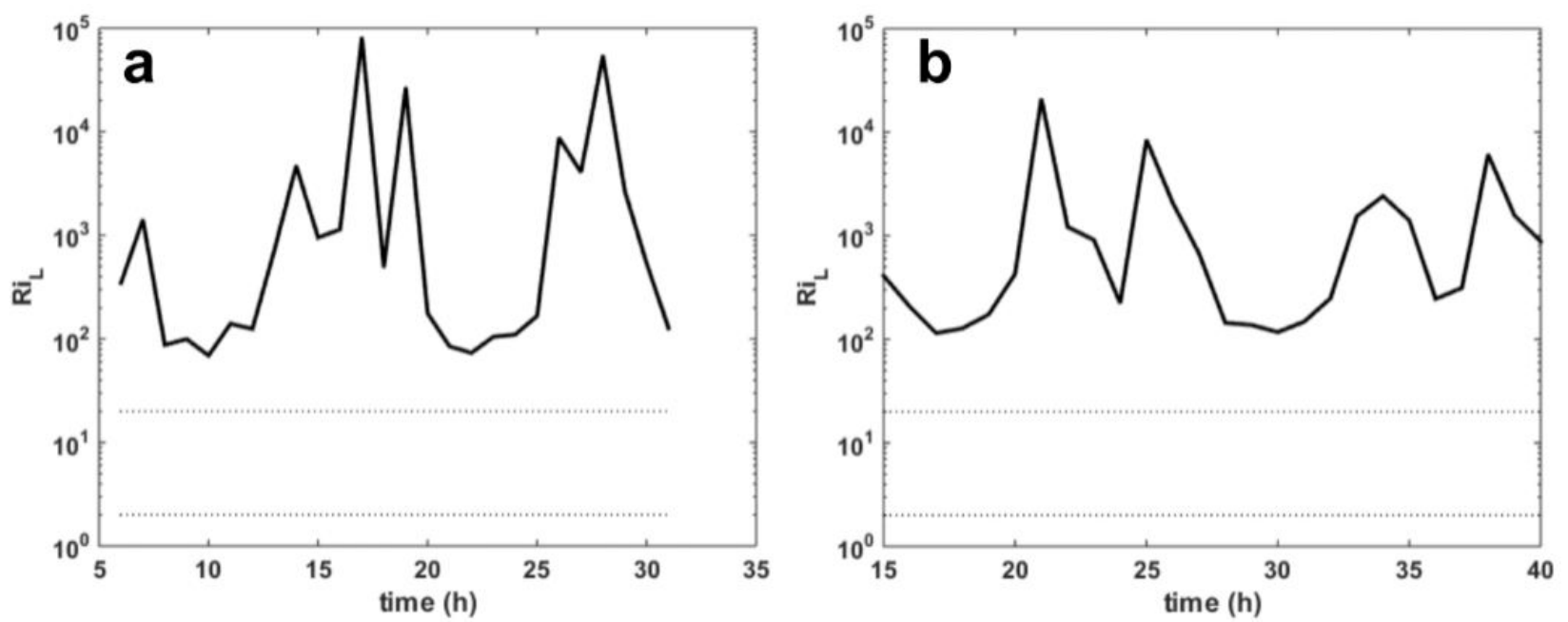

Figure 4. Temporal variation of the layer Richardson number $\left(\mathrm{Ri}_{\mathrm{I}}\right)$ in the spring (a) and neap (b) tide cycles (18-19 and 25-26 of February 2014, respectively).

(DYER, 1988). In São Francisco estuary, turbulence was not effective in generating mixing and in the spring and neap tidal cycles the water column tends to be stable for all the time $\left(\operatorname{Ri}_{\mathrm{L}}>20\right)$, with the lowest $\mathrm{Ri}_{\mathrm{L}}$ values at about $10^{2}$ in both periods and occurring at times of maximum currents. Mixing was suppressed even under strong flood currents higher than $-0.6 \mathrm{~m} . \mathrm{s}^{-1}$ in spring.

During the transitional fortnightly tidal modulation period there was no changes in the estuary classification (type $2 \mathrm{~b}$ - partially mixed and highly stratified), with advection and diffusion contributing with $34 \%$ and $66 \%$ to the net upstream salt flux, respectively, and conversely during neap tide, when they contributed with $56 \%$ and $44 \%$, respectively, and proving that both processes were important to the net upstream salt transport, as shown in the next section. These results also reveal that bottom generated mixing (significant tidal mixing) was not strong enough to overwhelm buoyancy effect, and mixing was fully suppressed throughout the tidal cycles (MIRANDA et al., 2004). In addition, the up-estuarine flow was not able to generate a significant tidal (bed-shear) mixing, increasing the possibility of density current formation and pronounced stratification (DYER; NEW, 1986; RALSTON; STACEY, 2005a, b).

This is an important finding as vertical stratification was key in define the estuarine classification which remained as partially mixed-highly stratified (type $2 b$ ) during the spring and neap tidal cycles. The diffusion and advection contributions played different roles in the net upstream salt fluxes where the former with $66 \%$ was the most important during the spring tide cycle, while the later with $56 \%$ was more significant during the neap tide cycle, which confirms the suggestion that tidal forcing and river discharge are important mechanisms controlling the local dynamic.

The salt wedge excursions towards the estuary head was recorded during the high slack-tide period and are shown in Figures $5 \mathrm{a}, 5 \mathrm{~b}$. Saline waters penetrated further upstream during the neap high slack water reaching $\sim 8.0 \mathrm{~km}$, compared to $\sim 6.8 \mathrm{~km}$ in the spring high slack water. The salinity lowest values at the most upstream station 17 (see Figure 1), reached $\sim 0.0$ and 0.9, during spring and neap tide, respectively, (Figures 5a, 5b). Similarly, the maximum salinity throughout the longitudinal sampling stations reached 36.8 and 36.6, at the estuary mouth, for spring and neap tide, respectively. Schettini et al. (2006), studying the Itajaí-Açu river estuary (south of Brazil) did see the presence of less saline waters at the middle estuary sector due to increasing river discharge. A similar feature was noticeable in our study where during strong river flow at $1.100 \mathrm{~m}^{3} / \mathrm{s}$ (spring tide) there was a shorter excursion in saline water reaching $\sim 6.8 \mathrm{~km}$ upstream, and a saline water penetration of $\sim 8.0 \mathrm{~km}$ during the neap tide which can be associated with the river discharge reduction to $900 \mathrm{~m}^{3} / \mathrm{s}$, affecting the downstream river strength and allowing the salt water intrusion toward the estuary upper reaches.

\section{Salt transport}

Although there was no changes in the estuary type classification, we found a significant difference in the net salt transport components revealing the sensitivity of the system to river discharge forcing and tidal currents (Figure 6). During the spring tidal cycle, the advective component generated by the river discharge was the main component in the net salt transport with $36.7 \mathrm{~kg} \mathrm{~m}^{-1} \mathrm{~s}^{-1}$. The tidal diffusion and gravitational circulation also played a role on the net salt transport contributing with -8.2 and $-12.9 \mathrm{~kg} \mathrm{~m}^{-1} \mathrm{~s}^{-1}$, respectively, flowing up-estuary, followed by the tidal pumping with a small contribution of $-3.6 \mathrm{~kg} \mathrm{~m}^{-1} \mathrm{~s}^{-1}$. In the neap tide, river discharge was the main down-stream forcing component reaching about $23.3 \mathrm{~kg} \mathrm{~m}^{-1} \mathrm{~s}^{-1}$, followed by the tidal diffusion with $3.5 \mathrm{~kg} \mathrm{~m}^{-1} \mathrm{~s}^{-1}$. The most important up-stream salt transport component was indicated by the gravitational circulation with $-9.7 \mathrm{~kg} \mathrm{~m}^{-1} \mathrm{~s}^{-1}$. The total salt transport for both spring and neap tide experiments revealed a down-stream flow pattern with 12.5 and $15.2 \mathrm{~kg} \mathrm{~m}^{-1} \mathrm{~s}^{-1}$, in spring and neap tide, respectively.

The present work showed that the dominant downstream advective salt transport in both spring and neap tide cycles is an indicative that there is little salt accumulation inside the São Francisco river estuary, at least for the time period (February 2014), and that there is a important role played by the riverine input in material exchange near the estuary mouth, even during 

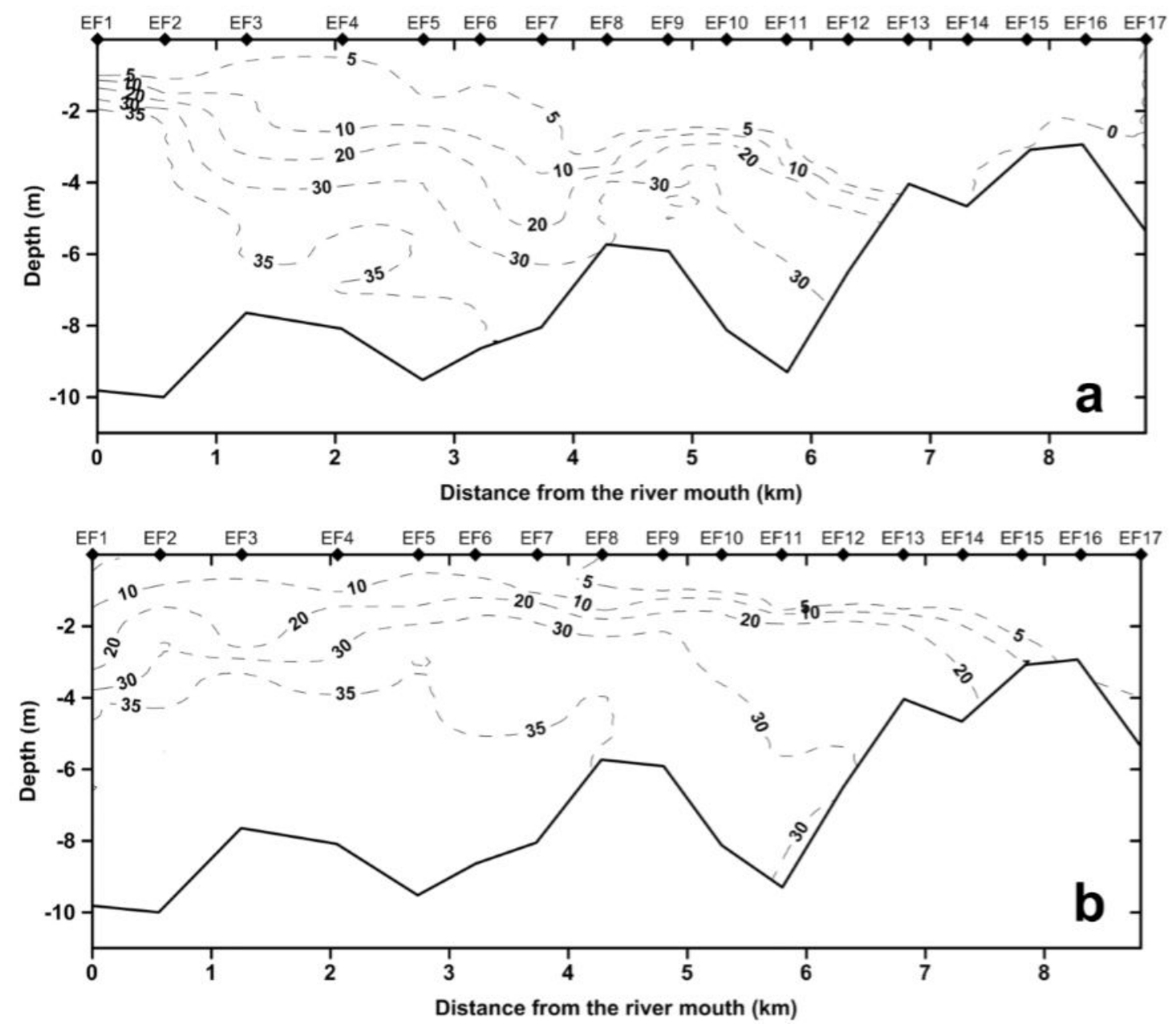

Figure 5. Longitudinal saline variation in the spring (a) and neap (b) tide cycles performed on 18 and 25 of February 2014, respectively.

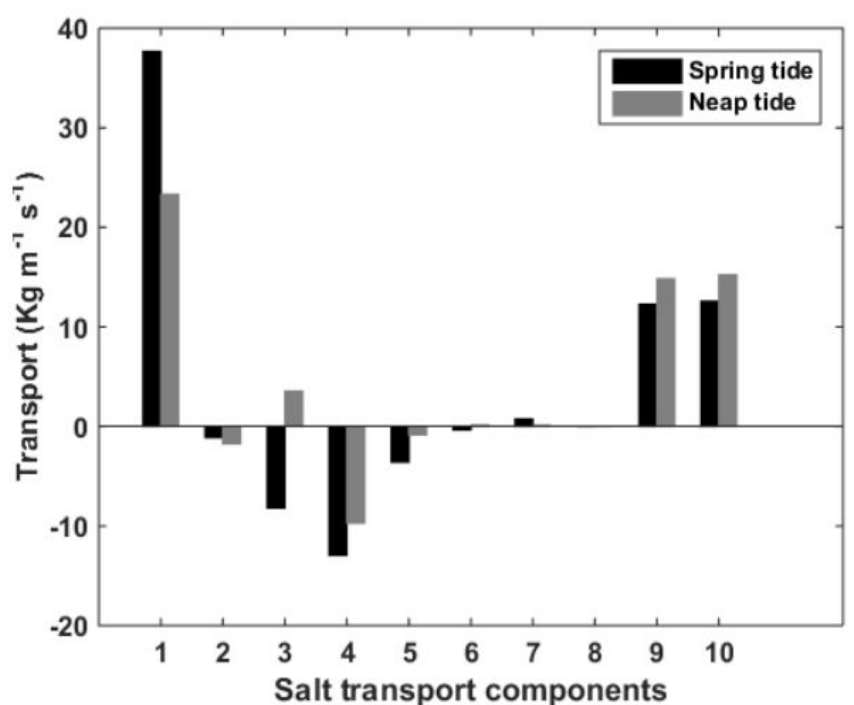

Figure 6. Mean advective salt transport components in the spring and neap tide cycles (18-19 and 25-26 of February 2014, respectively). (1)-Fluvial discharge; (2)-Stokes drift; (3)-Tidal diffusion; (4)-Gravitational circulation; (5)-Tidal pumping; (6)-Tidal shear; (7)-Residual circulation; Histograms (9) and (10) indicate the net salt transport calculated by integration and the algebraic sum of its components, respectively. reduction of river flow. Indeed, river discharge is an environmental factor that significantly affects the intensity of the down-stream flux and plays an important role on the salt balance estimation (DYER, 1995; MIRANDA; KJERFVE, 1998). For instance, the above component was reported in the Curimataú River, NE, Brazil, as the dominant forcing mechanisms in the system and determining the direction of the net flux at both neap-spring tides Miranda et al. (2004).

Comparing the experiment periods, Stokes drift played a small role in the upstream salt transport being almost negligible in the spring tide. Although, tidal diffusion is expected to be one of the predominant factors in controlling downstream salt transport (FISCHER et al., 1979), within the São Francisco estuary tidal diffusion played substantially different roles acting on the upstream and downstream salt transport, during spring and neap tides, respectively, similar to salt transport studies on large estuaries (KJERFVE, 1986; MIRANDA et al., 2004). This upstream contribution in spring could also be the result of greater current inversion in the water column during flood when compared to the neap tide (CAVALCANTE et al., 2013). This result is similar to that found in other estuaries, where estuarine salt transport and vertical shear dispersion have been found to be the dominant mechanism driving down-gradient salt flux (BOWEN; GEYER, 
2003; LERCZAK et al., 2006). The gravitational circulation was the second most important term in both spring and neap tides, which can be explained by the presence of freshwater increasing the thickness of the denser saline water resulting in the increase of the upstream baroclinic pressure gradient, in addition to the strong vertical gradient of salinity. Considering the magnitude in salt transport, tidal pumping contributed to the upstream salt transport in spring but was negligible in neap tide. These findings, as well as similar findings in previous observational studies of salt flux (HUNKINS, 1981; LEWIS; LEWIS, 1983; DRONKERS; VAN DE KREEKE, 1986), indicate that tidal pumping is often only of local significance to the overall salt balance in these partially mixed estuaries, and thus that the estuarine salt flux is the dominant contributor to the overall upstream salt transport.

\section{FINAL CONSIDERATIONS}

This study has explored for the first time how the variation in river input combined with tidal forcing during one spring-neap tide cycles would impact the water column stability and the coastal water incursion towards the interior areas of the São Francisco river estuary located at the border between Alagoas and Sergipe States, Brazil. Overall, current speed and high water column vertical stability revealed that the driving mechanism for the estuary circulation and mixing was mainly balanced by the river discharge and the tidal forcing associated with the gravitational circulation.

Although there was a reduction of $200 \mathrm{~m}^{3} / \mathrm{s}$ on river flow from spring to neap tide cycles, this difference did not seem to affect the resultant salt transport balance between experiments, where there was little difference in the components important in developing salt transport, revealing similar important components throughout both periods. It also indicated that the system was able to export the saline water downstream with no salt accumulation for the experiment periods.

Overall, we believe that the present research represents a substantial step in understanding the short-terms differences in hydrodynamic and correspondent salt transport within the São Francisco estuary. Further work should include longer temporal recording and a higher number of sampling stations throughout this system, to more completely examine the influence of river discharge reduction and tidal currents in salt transport mechanism along the São Francisco estuary.

\section{REFERENCES}

ALI, A.; LEMCKERT, C. J.; DUNN, R. J. K. Salt fluxes within a very shallow subtropical estuary. Journal of Coastal Research, v. 26, n. 3, p. 436-443, 2010. http://dx.doi.org/10.2112/08-1118.1.

ARAUJO, M.; MEDEIROS, C.; RIBEIRO, C. Energy balance and time-scales of mixing and stratification in the Jaboatão estuary NE-Brazil. Revista Brasileira de Oceanografia, v. 47, n. 2, p. 145-154, 1999. http://dx.doi.org/10.1590/S1413-77391999000200004.

BERNARDES, M. C.; KNOPPERS, B. A.; REZENDE, C. E.; SOUZA, W. F. L.; OVALLE, A. R. C. Land-sea interface features of four estuaries on the South America Atlantic coast.
Brazilian Journal of Biology $=$ Revista Brasileira de Biologia, v. 72, n. 3, p. 761-774, 2012. Supplement. PMid:23011302. http://dx.doi. org/10.1590/S1519-69842012000400011.

BOWEN, M. M.; GEYER, W. R. Salt transport and the time dependent salt balance of a partially stratified estuary. Journal of Geophysical Research, v. 108, n. C5, p. 27.1-27.14, 2003. http:// dx.doi.org/10.1029/2001JC001231.

CAVALCANTE, G. H.; FEARY, D. A.; KJERFVE, B. Effects of tidal range variability and local morphology on hydrodynamic behavior and salinity structure in the Caeté river estuary, North Brazil. International Journal of Oceanography, v. 2013, p. 1-10, 2013. http:/ /dx.doi.org/10.1155/2013/315328.

CAVAlCANTE, G. H.; KJERFVE, B.; KNOPPERS, B. A.; FEARY, D. Coastal currents adjacent to the Caeté Estuary, Pará Region, North Brazil. Estuarine, Coastal and Shelf Science, v. 88, n. 1, p. 84-90, 2010. http://dx.doi.org/10.1016/j.ecss.2010.03.016.

DAVID, L. T.; KJERFVE, B. Tides and currents in a twoinlet coastal lagoon: Laguna de Términos, México. Continental Shelf Research, v. 18, n. 10, p. 1057-1079, 1998. http://dx.doi. org/10.1016/S0278-4343(98)00033-8.

DOMINGUEZ, J. M. L. The São Francisco Strandplain: a paradigm for wavedominate deltas. In: DE BATIST, M.; JACOBS, P. (Ed.). Geology of siliclastic shelf seas. London: Geological Society, 1996. v. 117 , p. $217-232$.

DRONKERS, J.; VAN DE KREEKE, J. Experimental determination of salt intrusion mechanisms in the Volkerak estuary. Netherlands Journal of Sea Research, v. 20, n. 1, p. 1-19, 1986. http://dx.doi. org/10.1016/0077-7579(86)90056-6.

DYER, K. R. Tidally generated estuarine mixing processes. In: KJERFVE, B. (Ed.). Hydrodynamics of Estuaries: Estuarine physics. Boca Raton: CRC Press, 1988. v. 1, n. 4, p. 41-57.

DYER, K. R. Sediment transport processes in estuaries. In: PERILLO, G. M. E. (Ed.). Geomorphology and sedimentology of estuaries. New York: Elsevier, 1995. p. 423-449.

DYER, K. R. Estuaries: a physical introduction. 2nd ed. New York: John Wiley \& Sons, 1997. 140 p.

DYER, K. R.; NEW, A. L. Intermittency in estuarine mixing. In: WOLFE, D. A. (Ed.). Estuarine variability. New York: Academic Press, 1986. p. 321-339.

FISCHER, H. B.; LIST, E. J.; KOH, R. C. Y.; IMBERGER, J.; BROOKS, N. H. Mixing in inland and coastal waters. New York: Academic Press, 1979. 483 p.

HANSEN, D. V.; RATTRAY JUNIOR, M. New dimensions in estuary classification. Limnology and Oceanography, v. 11, n. 3, p. 319-325, 1966. http://dx.doi.org/10.4319/lo.1966.11.3.0319. 
HUNKINS, K. Salt dispersion in the Hudson estuary. Journal of Physical Oceanography, v. 11, n. 5, p. 729-738, 1981. http:/ / dx.doi. org/10.1175/1520-0485(1981)011<0729:SDITHE>2.0.CO;2.

KJERFVE, B. Circulations and salt flux in a well mixed estuary. In: VAN DE KREEK, J. (Ed.). Physics of shallow estuaries and bays. Berlin: Springer, 1986. p. 22-29.

KNOPPERS, B.; MEDEIROS, P. R. P.; SOUZA, W. F. L.; JENNERJAHN, T. The São Francisco estuary, Brazil. In: WANGERSKY, P. (Ed.). The Handbook of Environmental Chemistry: water pollution: estuaries. Berlin: Springer, 2005. p. 51-70.

KONDOLF, G. M. PROFILE: Hungry water: effects of dams and gravel mining on River Channels. Environmental Management, v. 21, n. 4, p. 533-551, 1997. PMid:9175542. http://dx.doi. org/10.1007/s002679900048.

LERCZAK, J. A.; GEYER, W. R.; CHANT, R. J. Mechanisms driving the time dependent salt flux in a partially stratified estuary. Journal of Physical Oceanography, v. 36, n. 12, p. 2296-2311, 2006. http://dx.doi.org/10.1175/JPO2959.1.

LEWIS, R. E.; LEWIS, J. O. The principal factors contributing to the flux of salt in a Narrow, partially Stratified Estuary. Estuarine and Coastal Marine Science, v. 16, n. 6, p. 599-626, 1983. http:// dx.doi.org/10.1016/0272-7714(83)90074-4.

MANTOVANELLI, A.; MARONE, E.; SILVA, E. T.; LAUTERT, L. F.; KLINGENFUSS, M. S.; PRATA, V. P. Jr; NOERNBERG, M. A.; KNOPPERS, B. A.; ANGULO, R. J. Combined tidal velocity and duration asymmetries as a determinant of water transport and residual flow in Paranaguá Bay estuary. Estuarine, Coastal and Shelf Science, v. 59, n. 4, p. 523-537, 2004. http:// dx.doi.org/10.1016/j.ecss.2003.09.001.

MEDEIROS, C.; KJERFVE, B. Hydrology of a tropical estuarine system: Itamaracá, Brazil. Estuarine, Coastal and Shelf Science, v. 36, n. 5, p. 495-515, 1993. http://dx.doi.org/10.1006/ecss.1993.1030.

MEDEIROS, P. R. P.; CAVALCANTE, G. H.; BRANDINI, N.; KNOPPERS, B. A. Inter-annual variability on the water quality in the Lower São Francisco River (NE-Brazil). Acta Limnologica Brasiliensia, v. 28, n. e5, p. 1-11, 2016.

MEDEIROS, P. R. P.; KNOPPERS, B. A.; CAVALCANTE, G. H.; SOUZA, W. F. L. Changes in nutrients loads (N, P, Si) in the São Francisco Estuary after the constructions of dams. Brazilian Archives of Biology and Technology, v. 54, n. 2, p. 387-397, 2011. http:// dx.doi.org/10.1590/S1516-89132011000200022.

MEDEIROS, P. R. P.; KNOPPERS, B. A.; SANTOS JUNIOR, R. C.; SOUZA, W. F. L. Aporte do material em suspensão e sua dispersão na Zona Costeira do Rio São Francisco (SE/AL). Geoquimica Brasiliensis, v. 21, n. 2, p. 209-228, 2007.
MILLIMAN, J. D.; FARNSWORTH, K. L.; JONES, P. D.; XU, K. H.; SMITH, L. C. Climatic and anthropogenic factors affecting river discharge to the global ocean, 1951-2000. Global and Planetary Change, v. 62, n. 3-4, p. 187-194, 2008. http://dx.doi.org/10.1016/j. gloplacha.2008.03.001.

MIRANDA, L. B.; BÉRGAMO, A. L.; RAMOS E SILVA, C. A. Dynamics of a tropical estuary: Curimataú River, NE Brazil. Journal of Coastal Research, v. 39, p. 697-701, 2004.

MIRANDA, L. B.; CASTRO FILHO, B. M.; KJERFVE, B. Circulation and mixing due to tidal forcing in the Bertioga Channel, São Paulo, Brazil. Estuaries, v. 21, n. 2, p. 204-214, 1998. http:// dx.doi.org/10.2307/1352469.

MIRANDA, L. B.; CASTRO, B. M.; KJERFVE, B. Princípios de Oceanografia Física de estuários. São Paulo: EDUSP, 2002. 414 p.

MIRANDA, L. B.; KJERFVE, B. Circulation and mixing due to tidal forcing in the Bertioga Channel, Sao Paulo, Brazil. Estuaries, v. 21, n. 2, p. 204-214, 1998. http://dx.doi.org/10.2307/1352469.

MIRANDA, L. B.; OLLE, E. D.; BÉRGAMO, A. L.; SILVA, L. S.; ANDUTTA, F. P. Circulation and salt intrusion in the Piaçaguera Channel, Santos (SP). Brazilian Journal of Oceanography, v. 60, n. 1, p. 11-23, 2012.

PARK, J. K.; DAVES, J. A. Mass flux estimation and mass transport mechanism in estuaries. Limnology and Oceanography, v. 35, n. 6, p. 1301-1313, 1990. http://dx.doi.org/10.4319/lo.1990.35.6.1301.

POFF, N. L.; ALLAN, J. D.; BAIN, M. B.; KARR, J. R.; PRESTEGAARD, K. L.; RICHTER, B. D.; SPARKS, R. E.; STROMBERG, J. C. The natural flow regime: a paradigm for river conservation and restoration. Bioscience, v. 47, n. 11, p. 769-784, 1997. http://dx.doi.org/10.2307/1313099.

RALSTON, D. K.; STACEY, M. T. Stratification and turbulence in subtidal channels through intertidal mudflats. Journal of Geophysical Research, v. 110, n. C08009, p. 1-16, 2005 a.

RALSTON, D. K.; STACEY, M. T. Longitudinal dispersion and lateral circulation in the intertidal zone. Journal of Geophysical Research, v. 110, n. C07015, p. 1-17, 2005 b.

RESTREPO, J. D.; KJERFVE, B. Magdalena river: interannual variability (1975-1995) and revised water discharge and sediment load estimates. Journal of Hydrology, v. 235, n. 1-2, p. 137-149, 2000. http://dx.doi.org/10.1016/S0022-1694(00)00269-9.

SALOMONI, S. E.; ROCHA, O.; LEITE, E. H. Limnological characterization of Gravataí River, Rio Grande do Sul. Acta Limnologica Brasiliensia, v. 19, p. 1-14, 2007.

SCHETTINI, C. A. F.; RICKLEFS, K.; TRUCCOLO, E. C.; GOLBIG, V. Synoptic hydrography of a highly stratified estuary. Ocean Dynamics, v. 56, n. 3-4, p. 308-319, 2006. http://dx.doi. org/10.1007/s10236-006-0066-1. 
TREPANIER, S.; RODRIGUEZ, M. A.; MAGNAN, P. Spawning migrations in landlocked Atlantic salmon: time series modelling of river discharge and water temperature effects. Journal of Fish Biology, v. 48, n. 5, p. 925-936, 1996. http://dx.doi. org/10.1111/j.1095-8649.1996.tb01487.x.

VAZ, N.; DIAS, J. M.; MARTINS, I. Dynamics of a temperate fluvial estuary in early winter. Global NEST Journal, v. 7, n. 3, p. 237-243, 2005.

\section{Authors contributions}

Geórgenes Cavalcante: Responsible for data collection, analysis and writing process.

Luiz Bruner de Miranda: Responsible for reviewing the data analysis and writing process.

Paulo Ricardo Petter Medeiros: Responsible for data collection and writing process. 